\title{
編集後記
}

Synthesiologyの発刊から、本号で9年目に入りました。 本号では、「3 次元 IC 積層実装技術の実用化への取り組み」 「レアメタル資源の安定供給を目指して」、「構成型研究に 扔けるシナリオ：その役割と表現」「太陽電池モジュール の信頼性向上と試験法開発に関するコンソーシアム研究」 に関する論文 4 編を打届け致します。研究の内容は多岐に わたりますが、実用化への取り組み、資源確保のための取 り組み、企業が共通基盤技術の開発をするためのコンソー シアムの設立 (取り組み) など、技術開発を社会へ活用する ための具体的事例を論述した、研究開発プロセスを系統立 ててまとめられています。これは、Synthesiologyの趣旨 である、研究活動とその社会寄与との間に横たわる「死の
谷」を埋める(克服する)為の活動記録であります。

産総研は第 4 期の中長期目標では「橋渡し」機能の強化が 求められて打り、個々の研究者が持つ研究ポテンシャルを 如何に進めて行けば実用化、事業化へ繋がるか（成功する のか)、大いに参考となるモノであります。

また、構成型研究におけるシナリオ：その役割と表現」 に記載されているように、現代の学術論文誌では、どの論 文も他分野の読者には理解不可能なものがほとんどである のに対し、シンセシオロジー誌に掲載された論文は、他分 野出身の読者や查読者にも理解可能な形で記述されていま す。是非ご一読を。

(編集幹事 高橋 正春) 


\title{
シンセシオロジー編集委員会
}

委員長 : 金山 敏彦

副委員長 : 湯元 昇、四元 弘毅

幹事 (編集及び查読)：池上 敬一、栗本 史雄、清水 敏美、富樫 茂子、山田 由佳

幹事 (普及) : 赤松 幹之、小林 直人 (早稲田大学)

幹事 (出版) : 高橋 正春

委員: 安宅 龍明、綾 信博、一村 信吾 (名古屋大学)、小賀坂 康志 (国立研究開発法人 科学技術振興機構)、小野 晃、

景山 晃、後藤雅式、竹下 満 (国立研究開発法人 新エネルギー・産業技術総合開発機構)、多屋 秀人 (株式会

社 J-Space)、内藤 茂樹、藤井 賢一、松井 俊浩 (国立研究開発法人 新エネルギー・産業技術総合開発機構)、

吉川 弘之 (国立研究開発法人 科学技術振興機構)

事務局 : 国立研究開発法人 産業技術総合研究所 企画本部広報サービス室内 シンセシオロジー編集委員会事務局

\author{
干 305-8560 つくば市梅園 1-1-1中央第 1 産業技術総合研究所企画本部広報サービス室内 \\ TEL : 029-862-6217 FAX : 029-862-6212 \\ E-mail: synthesiology-ml@aist.go.jp \\ ホームページ : http://www.aist.go.jp/aist_j/aistinfo/synthesiology/index.html
}

○本誌掲載記事の無断転載を禁じます。

\section{Synthesiology Editorial Board}

Editor in Chief: T. KANAYAMA

Senior Executive Editor: N. Yumoto, H. Yотsumoto

Executive Editors: K. Ikegami, C. Kurimoto, T. Shimizu, S. Togashi, Y. Yamada, M. Akamatsu, N. Kobayashi (Waseda University), M. TAKAHASHI

Editors: T. Ataka, N. Aya, S. Ichimura (Nagoya University), Y. Ogasaka (Japan Science and Technology Agency), A. Ono, A. Kageyama, M. Gotoh, M. Takeshita (New Energy and Industrial Technology Development Organization), H. Taya (J-Space Inc.), S. Naitou, K. Fujit, T. Matsui (New Energy and Industrial Technology Development Organization), H. YoshikawA (Japan Science and Technology Agency)

Publishing Secretariat: Public Relations Information Office, Planning Headquarters, AIST

c/o Public Relations Information Office, Planning Headquarters, AIST

Tsukuba Central 1, 1-1-1 Umezono, Tsukuba 305-8560, Japan

Tel: +81-29-862-6217 Fax: +81-29-862-6212

E-mail: synthesiology-ml@aist.go.jp

URL: http://www.aist.go.jp/aist_e/research_results/publications/synthesiology_e

Reproduction in whole or in part without written permission is prohibited. 


\section{「Synthesiology」の趣旨 一研究成果を社会に活かす知の蓄積 —}

科学的な発見や発明が社会に役立つまでに長い時間がかかったり、忘れ去られ葬られたりしてしまう ことを、悪夢の時代、死の谷、と呼び、研究活動とその社会寄与との間に大きなギャップがあることが 認識されている。そのため、研究者自身がこのギャップを埋める研究活動を行なうべきであると考える。 これまでも研究者によってこのような活動が行なわれてきたが、そのプロセスは系統立てて記録して論 じられることがなかった。

このジャーナル「Synthesiology - 構成学」では、研究成果を社会に活かすために行なうべきことを 知として蓄積することを目的とする。そのため本誌では、研究の目標設定と社会的価值、それに至る具 体的なシナリオや研究手順、要素技術の統合のプロセスを記述した論文を掲載する。どのようなアプロー チをとれば社会に活きる研究が実践できるのかを読者に伝え、共に議論するためのジャーナルである。

\section{Aim of Synthesiology - Utilizing the fruits of research for social prosperity -}

There is a wide gap between scientific achievement and its utilization by society. The history of modern science is replete with results that have taken life-times to reach fruition. This disparity has been called the valley of death, or the nightmare stage. Bridging this difference requires scientists and engineers who understand the potential value to society of their achievements. Despite many previous attempts, a systematic dissemination of the links between scientific achievement and social wealth has not yet been realized.

The unique aim of the journal Synthesiology is its focus on the utilization of knowledge for the creation of social wealth, as distinct from the accumulated facts on which that wealth is engendered. Each published paper identifies and integrates component technologies that create value to society. The methods employed and the steps taken toward implementation are also presented.

Synthesiology 第 9 巻第 1 号 2016 年 2 月 発行

編集 シンセシオロジー編集委員会

発行 国立研究開発法人 産業技術総合研究所 